\title{
6-アミノヘキシルグルコマンナンゲルを用いた高速液体 クロマトグラフィーによる血液凝固第VIII因子の分離
}

\author{
(1993 年 6 月 29 日 受理)
}

山口正人**山本哲郎 ・脇田正明・本里義明胡

\begin{abstract}
生体成分分離用の担体として好ましい種々の性質を持っているグルュマンナン (GM) ゲルに， アミ ノアルキル基を導入し，高速液体クロマトグラフィー（HPLC）飞よる血夜凝固第㚼因子 (FUII) の分 離に適用した。その結果，6-アミノヘキシル $(\mathrm{AH})$ 基を導入したものが，FUII の分離剤として最も適 していることがわかった。AH-GM ゲルの FUII 保持量は，市販の EAH Sepharose ${ }^{\circledR} 4$ B の 10 倍以 上であった。特に排除限界分子量が PEG 換算で 1000 万の AH-GM 10000 が最も高いFUII 保持量 を示した。また，AH-GM ゲルは， $\mathrm{AH}$ 基導入後も生体成分分離用の担体に必要な性質を保ち，通液 安定性にもすぐれていた。さらに，試料負荷時の流速が $2 \mathrm{~m} / \mathrm{h}$ 以上であっても，高い FVII 保持量を持 つことが確認できた。

一方，夾雑タンパク質の多いクリオプレシピテートでは，FUII の保持量は低下し，特に負荷量が多 い場合 HPLC による精製度は向上しにくいといら傾向が認められた。AH-GM ゲルを，血液製剤プ ロセスに適用する場合，イオン交換法などと併用することが好ましいと考兄られた。
\end{abstract}

\section{1 緒言}

血液凝固第UII因子（以後 FuII と略記する）は，正常人の血墏 中に約 $50 \sim 150 \mathrm{ng} / \mathrm{ml}$ 乙か含まれていない分子量約 30 万の糖タ ンパク質である1。しかし，血漿中では von Willebrand 因子 （以後 vWF と略記する）と複合体（FviIl-vWF）を形成して安定 化しており，その分子量は，約 100 万〜2000 万に及ぶことが報 告されている2》。先天的にこの FuII が欠損している病気が血友病 Aである。その治療には，根本的な方法はなく，久乏している FVIII を補給する補充療法が最も合理的かつ確実な方法とされて いる。

従来，FＵIII の補充には，七ト血將から低温沈殿法によって調製 したクリオプレシピテート（以後，クリオと略記する）が用いら れてきたが，精製度が低いため投与総タンパク質量が多く患者に 負担がかかること，夾雑タンパク質やウィルスの混入により副作 用を生じる危険性など多くの問題点が指摘されている3) 6)。この ような状沉の中，FＵII の精製度を高めるための手段として，近年 液体クロマトグラフィー（以後 LC と略記する）が適用されつつ ある(2 12)。

栗田工業株式会社, 160 東京都新宿区西新宿 3-4-7

$\dagger$ 熊本大学大学院医学研究科分子病理学講坐, 860 能本市 本荘 2-2-1

计 熊本工業大学工業化学科, 860 能本市池田 4-22-1

1）高橋芳右, 臨床病理, 特集号 70, 129(1987).

2) 藤村吉博, 血液と脈管, 20，1(1989).

3）三上定昭，日本臨床，39，3680(1981).

4) 神谷 忠, 臨床血液, 29, 666(1988).

5）川井 進, 藤本孟男, 臨床と研究，66，428(1989).

6）松田道生, 輸血と臨床, 7, 1018(1989).
さて，我国においては，モノクローナル抗体を用いたアフィニ ティークロマトグラフィー13) の導入により最優先課題であった 精製 FVIII 製剂の国内自給に一応の目処が付いた。従って，今後 は国内用製剂技術の改良に加兄て，開発途上国患者への製剂の 供給，あるいは開発途上国への製剤化技術の提供が求められるも のと考えられる。この場合, 精製コストが安く, しかも簢易な精 製プロセスが重視されるものと予想される。現在，国内において 主流となりつつあるモノクローナル抗体カラムを用いた調製法 ${ }^{14)}$ や遗伝子組換え技術を用いた調製法 ${ }^{16)}$ は調製費用が高額な上，精

7) M.P.W.M. te Booy, W. Riethorst, A.Faber, J. Over, B.W. Konig, Thromb. Haemostasis, 61, 234 (1989).

8) Y.Ruttyn, M.P. Brandin, M. A. Vijayalakshmi, J. Chromatogr., 491, 299(1989).

9) P. J. Fay, S. I. Chavin, D. Schroeder, F. E. Young, V. J. Marder, Proc. Natl. Acad. Sci. USA, 79, 7200 (1982).

10) L. O. Andersson, N. Forsman, K. Huang, K. Larsen, A. Lundin, B. Pavlu, H. Sandberg, K. Sewerin, J. Smart, Proc. Natl. Acad. Sci. USA, 83, 2979 (1986).

11) F. Rotblat, D. P. O'Brien, F. J. O'Brien, A. H. Goodall, E. G. D. Tuddenham, Biochemistry, 24, 4294 (1985).

12) A. Faure, M.Caron, D. Tepenier, J. Chromatogr., 257, 387(1983).

13）米国バクスター社, 特開平 1-13099 (1989).

14) Nikkei Biotechnology Annual Report (1993) pp. 290 292.

15） 日経バイオテク，281，1(1993). 
製過程や製品保存時の FUIII の失活を防ぐため大量の精製アルブ ミンを共存させており，共存アルブミンを計算に入れた最終製品 の実際の比活性はそれほど高いものではない。従って, F VII 製 剤の新しい調製法の開発は，世界的視野からは未だに社会的課題 と言える。

先に述べたように，FVIII-vWF 複合体は巨大分子として存在 しているため, カラムクロマトグラフィーによる精製の効率化に は, 孔径の大きな多孔性ゲルが必要である。最近, この要求を満 たすグルュマンナンゲル（以後 GM ゲルと略記する）が開発さ れた ${ }^{16)}$ 。

この GM ゲルは1）膨潤，収縮率が小さい，2）耐酸性，耐 アルカリ性に富み化学的に安定である，3）耐熱性にすぐれてい る17，4）マクロポフを有しかつ耐圧強度が高(18)，5）親水性に すぐれ反応性の高いOH 基を有する $\left.{ }^{18)} ， 6\right)$ 非特異的な吸着が少 ない，7）菌などによる分解，繁殖を起こしにくい,など生体高分 子の工業的クロマトグラフィ一用の担体として極めて好ましい特 改を持っている。

そこで,この GM ゲルに DEAE 基を導入してクリオからの F诅 の分離に適用したところ，先に報告したごとく，イオン交 換体を用いた調製法としては，満足できる成果を得た ${ }^{16)}$ 。また， 通常の LC のみならず，高速液体クロマトグラフィー（以後 HPLC と略記する）への応用も可能であった。

今回, GM ゲルの適用分野の払大をはかるため，F叫に対する 親和性が高く, 経済的な修飾基の開発について調查した結果, あ る種のアミノアルキル基を既存のソフトゲルに導入した研究が報

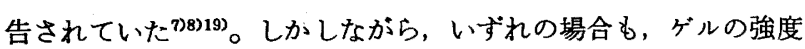
不足, F VIII 保持量が低いなど多くの課題が残っている。

そこで著者らは，GM ゲルを担体として用いれば，これらの課 題が解決できると考え, GM ゲルにアミノアルキル基を道入し, HPLC によるクリオからの F UII の分離を検討したので報告す る。

\section{2 実験}

\section{1 血獎, 試菜および各種ゲル}

精製クルコマンナンは, 清水化学(株)から賤入した。新鮮凍結 血獎は日本赤十字社から購入し, 脱フィブリノーゲン処理を行っ ていない粗製クリオブレシピテートは，化学及血清療法研究所 （化血研）から恵与された。テストチーム® FVII，因子標準血 墏，F伹欠損血漿は，それぞれ Kabi Vitrum AB 社, Dade 社, George King Biomedical 社製を用いた。EAH Sepharose ${ }^{\circledR}$ $4 \mathrm{~B}, \quad$ Sepharose ${ }^{\circledR}$ CL-4 B, Sephacryl ${ }^{\circledR}$ S-1000 は Pharmacia 社から, Toyopearl ${ }^{\circledR} \mathrm{HW}-75$ (C) は東ソー(株)から購入した。 その他の試薬は Sigma 社, 和光純薬工業(株), 半井化学(株)製

16) M. Yamaguchi, T. Yamamoto, T. Tomoda, Y. Motozato, Bull. Chem. Soc. Jpn., 66, 639(1993).

17）山口正人, 飯泉太郎, 山本哲郎, 本里義明, 日化, 1993, 837.

18）本里義明, 伊原博隆, 中村 貢, 芝 真砂代, 平山忠一, 日化, 1988,61 .

19) M.P.W.M. TE Booy, A. Faber, E. D. Jonge, E.P. Wolterink, W. Riethorst, T. Beugeling, A. Bantjes, J. Over, B.W. Konig, J. Chromatogr., 503, 103 (1990).
を用いた。

\section{2 多孔質グルコマンナン球状粒子の調製}

本誌ですでに報告されている方法 ${ }^{18)}$ 基づいて調製された GM ゲルを用いた。

\section{3 アミノアルキルゲルの調製}

Riethorst の論文 ${ }^{20)}$ を基に各種アミノアルキルゲルの調製を行 った。所定量のゲルを真空乾燥し，ゲル体積の 2 倍量の $N, N-シ ゙$ メチルホルムアミド (DMF) の中で $N, N^{\prime}$-カルボニルジイミダ ゾール (CDI) と反応させた。CDI 活性化ゲルをDMF で洗浄し た後, ゲルと同体積の DMF 中で 1,6-ジアミノへキサン, 1,4ジフミノブタンと反応させることにより，6-アミノヘキシル（以 後 $\mathrm{AH}$ と略記する）ゲル，4-アミノブチル（以後 $\mathrm{AB}$ と略記す る）ゲルを得た。また，CDI 活珄化ゲルをゲルと同体積のDMF/ 水酸化ナトリウム混合液中で 5-アミノ吉草酸と反応させ，続い てゲルと同体積の DMF 中で塩酸 1-エチル-3-(3-ジメチルア フプロピル)カルボジイミドおよび $N$-ヒドロキシスクシンイミ ドを反応させた。最後にゲルと同体積の $0.1 \mathrm{M}$ 炭酸水素ナトリ

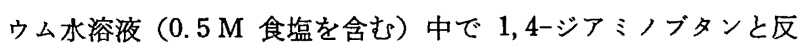
応させることにより４4-(4-アミノブチルカルバモイル)ブチル （以後 $\mathrm{ABCB}$ と略記する）ゲルを得た。

一方, 乾燥させると元の球状ゲルに戻りにくい Sepharose $\mathrm{e}^{\circledR}$ CL-4 B ではゲルをグラスフィルターに取り, DMF で洗浄して 得られた湿潤ゲルを, ゲルと同体積の DMF 中でCDI と反応さ せて CDI 活性化 Sepharose を得た。以後の工程は, 上記ゲルの 場合と同様に行った。

\section{4 クリオの調製}

クリオの調製は Thorell らの方法21"参考に行った。プロテア 一ゼインヒビターとして, 大豆トリプシンインヒビター(SBTI), ヘンンズアミジン, diisopropyl phosphorofluoridate を原料血墏に 対して, それぞれ $4 \mu \mathrm{M}, 12.5 \mathrm{mM}, 1 \mathrm{mM}$ の最終濃度になるよ ら添加した。脱フィブリノーゲン処理を行ったクリオの比活性 は, 今回 $0.7 \sim 6.0 \mathrm{U} / \mathrm{mg}$-protein であった。クリオは $55 \mathrm{mM} ク$ エン酸緩衝液（pH 7.4）に溶解し, 使用するまで $-70^{\circ} \mathrm{C}$ で涷結 保存した。

一方, 化血研より恵与されたクリオブロックは, $-70{ }^{\circ} \mathrm{C}$ で涷 結保存した。使用の際, 同様 $55 \mathrm{mM}$ クエン酸緩衝液 ( $\mathrm{pH} 7.4$ ) に溶解した。脱フィブリノーゲン処理を行っていない粗製クリオ の比活性は $0.13 \sim 0.24 \mathrm{U} / \mathrm{mg}$-protein であった。

\section{5 各種測定}

2.5.1 FVIII の測定：FVIII の測定は，F 䜣 欠損血獎とコアグ ロメーター (Amelung Coagulometer KC 1 A) を用いた凝固時間 法とテストチーム® F VIII を用いた発色法によって行った。発色 法にはエンドポイント法と初速度測定法がある22。今回，主に正 確さ，再現性の点ですぐれているテストチーム®FVIII 用いたエ ンドポイント法を採用した。

2.5.2 アミノアルキル基導入量の測定: 各種アミノアルキル 基の導入量の測定は, 真空乾燥して科量したゲルに所定量の $0.005 \mathrm{~N}$ 塩酸を加えて一晚静置し， $0.01 \mathrm{~N}$ 水酸化ナトリウムで

20) Waander Riethorst, Twente 大学 学位論文(1988).

21) L. Thorell, N. Blombäck, Trombosis Res., 35, 431 (1984).

22）第一化学楽品(株), テストチーム® FVIII カタログ(1989). 
逆滴定して求めた。終点はフェノールフタレインを用いて決定し た。この場合, ゲルに導入されたアミノ基の量に比例して，塩酸 が消費されると仮定した。

2.5.3 校正曲線の作成：調製したカラムの排除限界分子量(以 後 Mlim と略記する) は, 分子量の異なるポリェチレングリコ ール (PEG) を標準試料に用い, 得られた溶出曲線のピーク溶出 量とその試料の分子量の関係から求めた。校正曲線の直線部分は 次式で示されることがわかっている ${ }^{23)} 。$

$$
\log M=\beta-\alpha\left(V_{\mathrm{e}} / V_{\mathrm{t}}\right) \times 100
$$

$V_{\mathrm{e}}$ は分子量 $M$ の試料の溶出容積, $V_{\mathbf{t}}$ はゲル床の容積である。 また，カラムの Mlim がかなり大きい場合，中央の直接部分を $V_{\mathrm{o}}$ (ゲル床間隙容積) の值まで外插して求めた。

\section{6 バッチ法による FVIII の保持実験}

表面をシリコーン処理し，F UIII などタンパク質が吸着しに くくなっている内容積 $1.5 \mathrm{ml}$ のサンプル管（フナコシ製マルチ リューブチュープ(B) に, $500 \mathrm{mM}$ 塩化カルシウムと $2 \mathrm{M}$ 食塩 を含む $20 \mathrm{mM}$ トリスー塩酸緩衝液（pH 7.4）で十分洗浄した後，

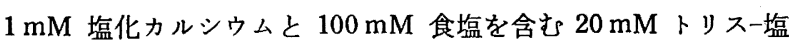

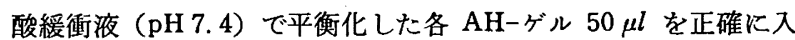
れた。続いて所定量 $(700 \sim 1100 \mu l)$ のクリオ溶液を入れ，室温 $\left(20^{\circ} \mathrm{C}\right)$ で 1 時間，振とう機を用いて FVIII を保持させた。平衡反 応後, 遠心分離機を用いてゲルとクリオ溶夜を $10000 \mathrm{rpm}$ で 3 分間の条件で固液分離し，クリオ溶液中に残存する FVIII を定量 することで, ゲルに保持された FVIII の量を求めた。

\subsection{FVIII の HPLC による分離}

2.6 と同様十分洗浄した各種 $\mathrm{AH}$-ゲルをステンレススチール 製カラム（6 mm×100 mm または $10 \mathrm{~mm} \times 100 \mathrm{~mm})$ に詰め, 1 $\mathrm{mM}$ 塩化カルシウムと $100 \mathrm{mM}$ 食塩を含む $20 \mathrm{mM}$ トリスー塩酸 緩衝液（pH 7.4）を 10 ベッド以上流して，カラム内を平衡化し た。その後,クリオ溶液をカラムに負荷し， $100 \mathrm{mM}$ 食塩を含む $20 \mathrm{mM}$ トリス-塩酸緩衝液（pH 7.4）の塩化カルシウム濃度を 変化させながら F UII を溶出させた。HPLC は島津製作所製 LC-6 A システムもしくは LKB 2249 システムを用いた。クリオ 溶液の量が多い場合は, Pharmacia 製 Super-loop ${ }^{\circledR}$ を用いて負 荷を行った。

\section{3 結果および考察}

\section{1 クリオ溶液の調製}

血墏中の F VII を効率良くクリオプレシピテートにする方法

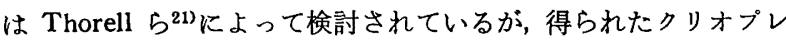
シピテートの再可溶化は，高分子物質であるだけに必ずしも容易 ではない。とりわけ，HPLC 用の調製に関しては報告が見られな かったので, 今回クリオブロックの溶解方法, 前処理法について も改めて検討を行った。

3.1.1 クリオフロックの溶解方法 : 分別沈殿法およびクロマ トグラフィーにおける試料負荷は，試料濃度をできるだけ高く し，液量を少なくするといらのが原則である。しかしりリオのよ らに，溶けにくく，不溶解性のタンパク質が多いものは，溶液

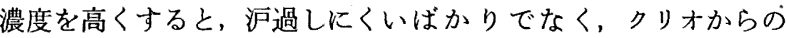

23) K. A. Granath, P. Flodin, Makromol. Chem., 48, 160 (1961).
FVII の回収率にも大きく影響すると考えられる。そこで溶解条 件についていくつか検討を行った。

クリオブロックの溶解方法については，ホモジナイザーが最も 簡易迅速であった。密閉性の高いものは, テフロン棒と受器の壁 に，クリオが接着剤のよらに付着し，かきまぜできなくなってし まい良くなかった。逆に少し隙間があるものは、クリオをよくか きまぜ，溶解できた。なお，FＵII は空気との接触で急速に変性 することが報告されており ${ }^{24)}$ ，できるたけ泡立てないよ5留意し た。

次に温度について考察すると，一般に F妍は低温である程 安定であるため, 溶解する緩衝液を冷やす方が好ましい。しか し，クリオ中にはフィブリノーゲン，フィブロネクチンなどのポ リマーを形成しやすいタンパク質が多く含まれ，冷却すると析出 するため，温度を下げることはできなかった。逆に $37^{\circ} \mathrm{C} て ゙$ て温 した緩衝夜を用いて溶解した場合，クリオは極めて良く溶けるも のの，F䜣 の失活が早く，使用できなかった。これはクリオ中に 存在する FII, FX, Protein C など FVIII を失活せせるプロテア 一ゼの働きが活発になったためと考えた。いろいろ試行錯誤の結 果, 室温に放置した緩衝液に $-70^{\circ} \mathrm{C}$ に保存してあったクリオブ ロックをいれ，全体が膨潤するまで待ち，その後はさみで細断 し，ホモジナイザーでかきまぜ，溶解するといら方法が，クリオ の溶解性を損ならことなく、また F III の失活を少なくできるこ とがわかった。

最後にクリオ量に対する緩衝液量について検討した結果を図 1 にまとめた。図のプロットはすべて，見かけ上溶液状態になって いたクリオの組成である。しかし実際沪過後分析を行った結果， クリオ $1 \mathrm{~g}$ あたりからの FVIII の回収量（率）および比活性に 大きな差が認められた。緩衝液量が多くなるにつれて，1 $\mathrm{g}$ あた りのクリオからの F 䜣 回収量が向上し, 比活性が高くなる傾 向が見られた。これは，フィルターを通らないクリオの小さな塊 の中に, FVIII が含まれて扣り，液量を多くするにつれて，クリ オ全体の溶解性が良くなった結果であると判断した。好ましいク リオに対する緩衝液量としては, 約 $80 \mathrm{mg} / \mathrm{m} l$ であり, それ以上 多くすると，逆に FuII の回収率は低下した。最も良い条件で は, $1 \mathrm{~g}$ のクリオから 45 48 U の F VIII が回収できた。クリ オ $1 \mathrm{~g}$ は約 $75 \mathrm{ml}$ の血漿から調製されており, $1 \mathrm{ml}$ の血獎は 1 $\mathrm{U}$ の FVIII を含んでいるため, 60〜64\% の回収率と考兄られ た。

3.1.2 クリオ溶液の前処理 : $55 \mathrm{mM}$ クエン酸緩衝液に溶解し たクリオ溶液は不溶解物が多く，そのままではカラムに負荷でき ないため, 何らかの前処理が必要であると判断した。そこで遠心 分離と市肘のディスク型フィルターを用いて比較した。結果を表 1 に示した。遠心分離では, クリオ溶液の組成の変化が大きく, 特に FVIII の損失が大きかった。一方, ディスク型フィルターでは F IIII の損失は比較的少なく，前処理に有効であることがわかっ た。フィルターのサイズ, 孔径が同じ場合, クラボウ製ステラデ ィスク $\otimes_{25}(0.45 \mu \mathrm{m})$ が最も多量のクリオ溶液を処理すること ができたため，本実験では主にこのフィルターを使用した。

3.1.3 クリオ溶液中の FVIII の安定性：FVIII の失活を防 ぐために, 緩衝液中にショ糖やアルブミンを添加した状態で HPLC により分離する方法が報告されており ${ }^{12)}$ ，また，実際高純

24）松田道生, Current Therapy, 7, 1018(1989). 


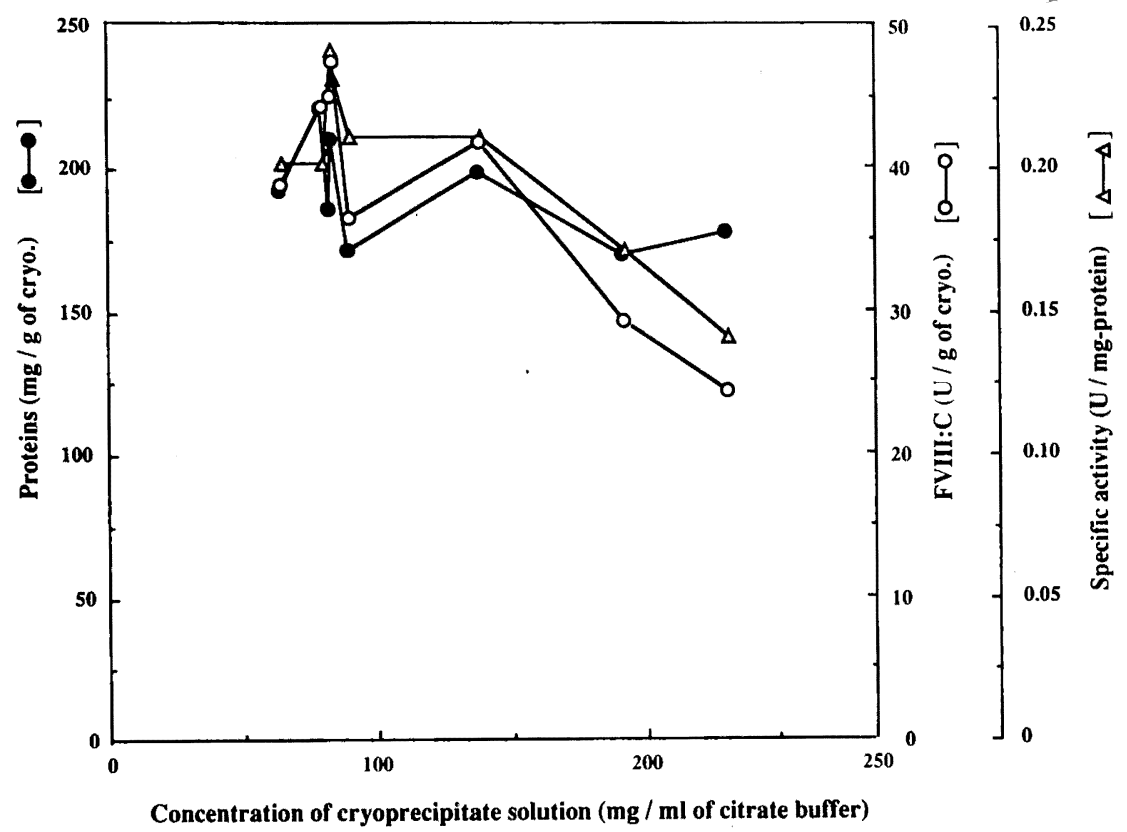

Fig. 1 Correlation between concentration of cyroprecipitate solution and obtained amount of proteins including $\mathrm{F}$ VII

Crude cryoprecipitate prepared by the Chemo-Sero-Therapeutic Research Institute in a conventional way without defibrinogenation, and stored at $-70^{\circ} \mathrm{C}$ in blocks, was dissolved into $55 \mathrm{mM}$ citrate buffer ( $\mathrm{pH} \mathrm{7.4)} \mathrm{by} \mathrm{using} \mathrm{a} \mathrm{Potter's} \mathrm{homegenizer}$ and passed through a $0.45 \mu \mathrm{m}$ pore size filter. The soluble fraction of crude cryoprecipitate was freshly prepared in each experiment.

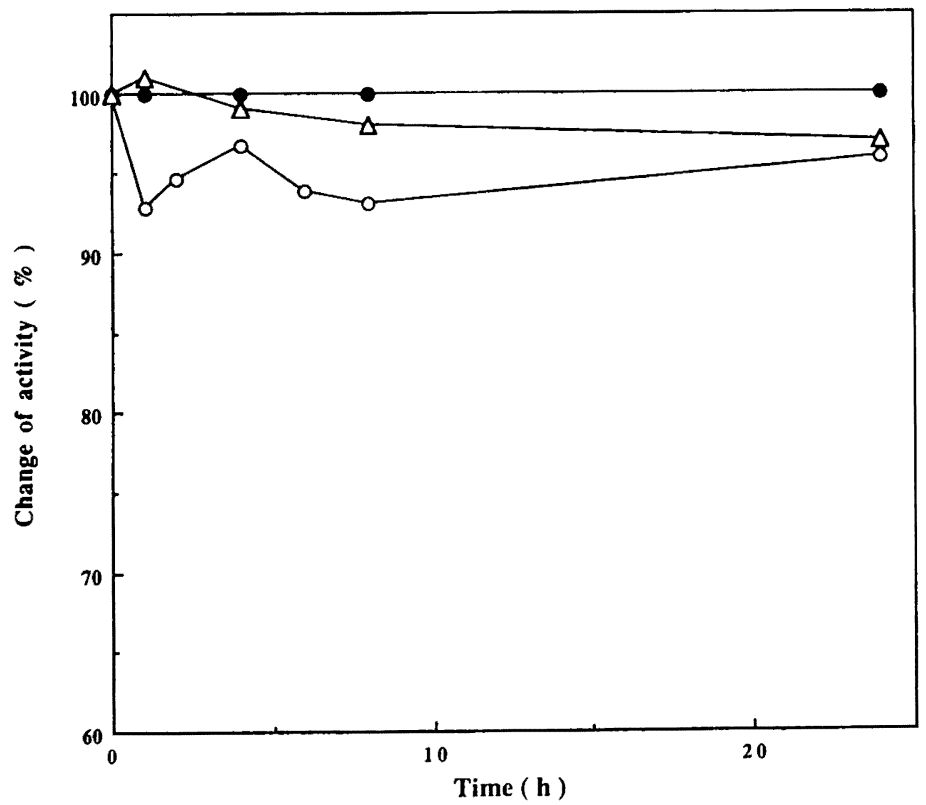

Fig. 2 Stability of F VIII on standing

(O) Factor assay reference plasma (Dade), F UII : $1.25 \mathrm{U} / \mathrm{ml}$, S. A. : $0.02 \mathrm{U} / \mathrm{mg}$-protein

(O) Cryoprecipitate, FVII : $2.82 \mathrm{U} / \mathrm{ml}$, S. A. : $2.47 \mathrm{U} / \mathrm{mg}$-protein

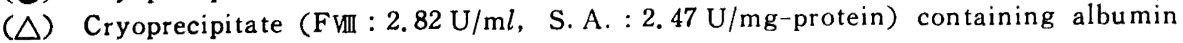
at the concentration of $1 \mathrm{mg} / \mathrm{ml}$

The final S.A. is $1.32 \mathrm{U} / \mathrm{mg}$-protein. 
Table 1 Change of composition of cryoprecipitate solution by pretreatments

\begin{tabular}{llccc}
\hline & & Before (B) & After (A) & A-B/B (\%) \\
\hline Centrifugation $^{a)}$ & FVII : $\mathrm{C}(\mathrm{U} / \mathrm{ml})$ & 6.9 & 4.5 & -34.8 \\
& Proteins $(\mathrm{mg} / \mathrm{ml})$ & 34.7 & 25.2 & -27.4 \\
& Specific activity (U/mg-P.) & 0.20 & 0.18 & -10.0 \\
Filtration $^{b)}$ & FVII : C $(\mathrm{U} / \mathrm{ml})$ & 6.5 & 5.7 & -12.3 \\
& Proteins $(\mathrm{mg} / \mathrm{ml})$ & 36.0 & 32.5 & -9.7 \\
& Specific activity (U/mg-P.) & 0.18 & 0.18 & 0 \\
\hline
\end{tabular}

a) $12000 \mathrm{rpm} \times 20 \mathrm{~min}$.

b) $0.45 \mu \mathrm{m}$ pore size filter.
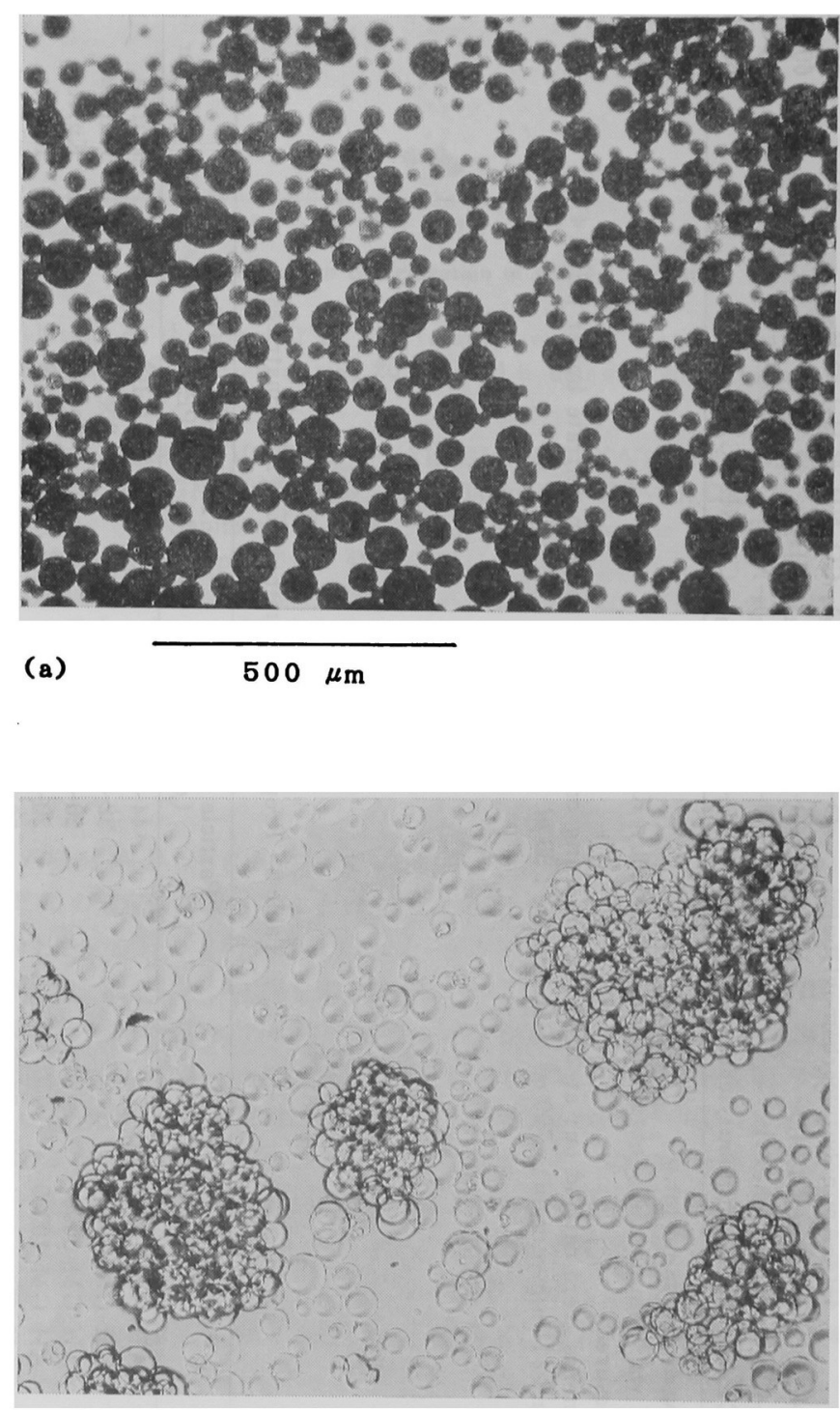

(b)

$500 \mu \mathrm{m}$

Fig. 3 Optical microphotographs of $\mathrm{AH}$ matrices

(a) AH-GM 2000, AH content: $53 \mu \mathrm{mol} / \mathrm{ml}$-gel, (b) AH-Sepharose CL-4 B, AH content : $40 \mu \mathrm{mol} / \mathrm{ml}$-gel. Instrument : Olympus IMT-2 
Table 2 Properties of aminoalkyl (AA) matrices

\begin{tabular}{|c|c|c|c|c|c|c|c|}
\hline No. & Material & Ligand & Chemical structure & $\begin{array}{l}\text { AA content }{ }^{c)} \\
(\mu \mathrm{mol} / \mathrm{ml}-\mathrm{gel})\end{array}$ & $\begin{array}{l}\text { Particle } \\
\text { diameter } \\
\quad(\mu \mathrm{m})\end{array}$ & $\begin{array}{l}\text { Exclusion } \\
\text { limite) } \\
\text { (as PEG) }\end{array}$ & $\begin{array}{l}\text { Retained amount } \\
\text { of } F W^{d)} \\
(U / m g-g e l)\end{array}$ \\
\hline $1^{a)}$ & AB-GM 1000 & 4-Aminobutyl & $-\mathrm{O}-\mathrm{CO}-\mathrm{NH}-\left(\mathrm{CH}_{2}\right)_{4}-\mathrm{NH}_{2}$ & 87 & $44 \sim 149$ & $1 \times 10^{8}$ & 5.5 \\
\hline $2^{a)}$ & AH-GM 1000 & 6-Aminohexyl & $-\mathrm{O}-\mathrm{CO}-\mathrm{NH}-\left(\mathrm{CH}_{2}\right)_{\mathrm{B}^{-}}-\mathrm{NH}_{2}$ & 57 & $44 \sim 149$ & $1 \times 10^{\circ}$ & 15.1 \\
\hline $3^{a)}$ & $\mathrm{ABCB}-\mathrm{GM} 1000$ & 4-(4-Aminobutylcarbamoyl)butyl & $-\mathrm{O}-\mathrm{CO}-\mathrm{NH}-\left(\mathrm{CH}_{2}\right)_{4}-\mathrm{CO}-\mathrm{NH}-\left(\mathrm{CH}_{2}\right)_{4}-\mathrm{NH}_{2}$ & 59 & $44 \sim 149$ & $1 \times 10^{8}$ & 2.5 \\
\hline $4^{b)}$ & AB-Sepharose CL-4B & 4-A minobutyl & $-\mathrm{O}-\mathrm{CO}-\mathrm{NH}-\left(\mathrm{CH}_{2}\right)_{4}-\mathrm{NH}_{2}$ & 80 & $60 \sim 140$ & $3 \times 10^{5}$ & 12.5 \\
\hline $5^{b)}$ & AH-Sepharose CL-4B & 6-Aminohexyl & $-\mathrm{O}-\mathrm{CO}-\mathrm{NH}-\left(\mathrm{CH}_{2}\right)_{6}-\mathrm{NH}_{2}$ & 40 & $60 \sim 140$ & $3 \times 10^{5}$ & 15.7 \\
\hline $6^{b)}$ & ABCB-Sepharose CL-4B & 4-(4-Aminobutylcarbamoyl)butyl & $-\mathrm{O}-\mathrm{CO}-\mathrm{NH}-\left(\mathrm{CH}_{2}\right)_{4}-\mathrm{CO}-\mathrm{NH}-\left(\mathrm{CH}_{2}\right)_{4}-\mathrm{NH}_{2}$ & 33 & $60 \sim 140$ & $3 \times 10^{5}$ & 2.6 \\
\hline
\end{tabular}

a) GM spheres used were the same lot.

b) Sepharose ${ }^{\circledR}$ CL-4B was commercially obtained and prepared by Kurita.

c) Experimentally measured.

d) Batch-wise experiments were carried out at $20^{\circ} \mathrm{C}$ for $1 \mathrm{~h}$ using cryoprecipitate solution (citrate buffer $\mathrm{pH} 7.4$ ).

F III : $1.25 \mathrm{U} / \mathrm{ml}$ (ca. $2 \mathrm{U} / \mathrm{mg}$-protein) $\times 700 \mu l$ Gel volume $: 50 \mu l$

Table 3 Properties of 6-aminohexyl( $\mathrm{AH})$ matrices

\begin{tabular}{|c|c|c|c|c|c|c|}
\hline No. & Material & $\begin{array}{l}\text { Particle diameter } \\
\qquad(\mu \mathrm{m})\end{array}$ & $\begin{array}{l}\text { Exclusion limit }{ }^{b l} \\
\quad \text { (as PEG) }\end{array}$ & Maker & $\begin{array}{l}\text { AH conten } \mathrm{t}^{b)} \\
\left(\mu \mathrm{mol} / \mathrm{ml} l-\mathrm{gel}^{2}\right)\end{array}$ & \\
\hline 1 & AH-GM 1000 & $44 \sim 149$ & $1 \times 10^{6}$ & Kurita & 57 & \\
\hline 2 & AH-GM 2000 & $32 \sim 125$ & $2 \times 10^{8}$ & Kurita & 53 & \\
\hline 3 & AH-GM 3000 & $20 \sim 44$ & $3 \times 10^{6}$ & Kurita & 71 & \\
\hline 4 & AH-GM 10000 & $20 \sim 44$ & $1 \times 10^{7}$ & Kurita & 86 & \\
\hline 5 & AH-Toyopearl HW-75(C) & $50 \sim 100$ & $1.5 \times 10^{6}$ & Tosohe) & 66 & \\
\hline 6 & AH-Sephacryl S-1000 & $40 \sim 105$ & $2 \times 10^{6}$ & Pharmacia ${ }^{c)}$ & 14 & \\
\hline 7 & AH-Sepharose CL-4B & $60 \sim 140$ & $3 \times 10^{5}$ & Pharmacia ${ }^{c)}$ & 40 & 1 \\
\hline $8^{a)}$ & EAH Sepharose 4B & $60 \sim 140$ & $1 \times 10^{5}$ & Pharmacia & $7 \sim 11^{d)}$ & \\
\hline
\end{tabular}

a) Commercially obtained.

b) Experimentally measured.

c) Matrix support was commercially obtained and 6-aminohexylated by Kurita.

d) Announcement by the company. 


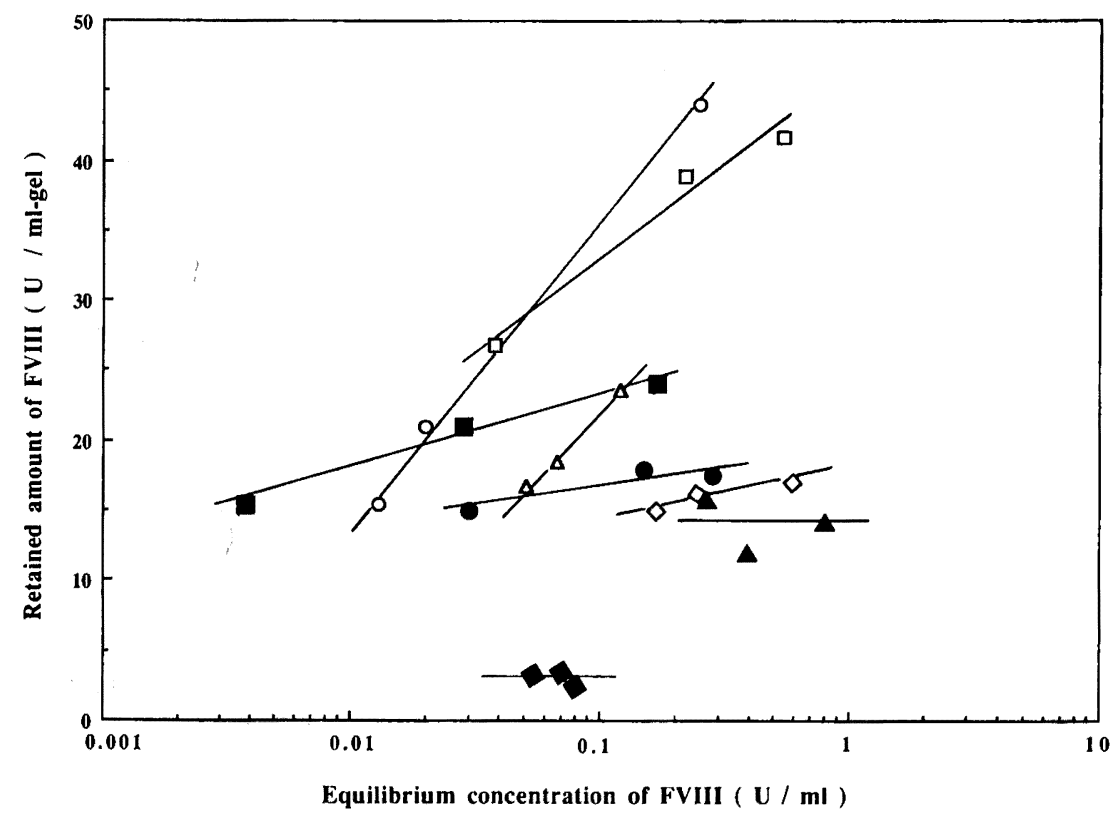

Fig. 4 Correlation of the amount of FVII retained on AH matrix to its concentration. Experiments were carried out at $20^{\circ} \mathrm{C}$ for $1 \mathrm{~h}$ using cryoprecipitate solutions (55 $\mathrm{mM}$ citrate buffer, $\mathrm{pH} \mathrm{7.4)}$

(O) AH-GM 10000, ( $\square$ ) AH-GM 3000, ( $\triangle$ ) AH-GM 2000,

(১) AH-GM 1000, (O) AH-Toyopearl HW-75(C),

(ロ) AH-Sephacryl S-1000, (A) AH-Sepharose CL-4B,

Conditions

( ) EAH Sepharose ${ }^{\circledR} 4 \mathrm{~B}$

Gel volume : $50 \mu l$

Cryoprecipitate : $1.25 \mathrm{U} / \mathrm{ml}(\operatorname{lot} 1) \times 700 \mu l$

$1.39 \mathrm{U} / \mathrm{ml}(\operatorname{lot} 2) \times 700 \mu l$

$1.81 \mathrm{U} / \mathrm{ml}($ lot 3$) \times 700 \mu l$

(ca. $2 \mathrm{U} / \mathrm{mg}$-protein)

度の F Ull 製剤にはアルブミンが皮定剤として添加されてい $ろ^{25)}$ 。調製したクリオ溶液中の F VIII の安定性を調べることは, HPLC によるFVIII の回収率を向上させる上で大切と考えられ るため，経時変化に伴う F VIII の活性を测定した。結果を図 2 に 示した。因子標準血漿, クリオ溶液, クリオ溶液にフルブミンを 添加したものでは，共に 24 時間経っても FVIII の失活はほとん

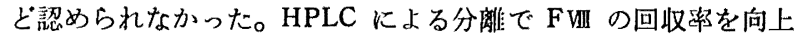
させるには，できるだけ高い温度は避け，FUII などが吸着しにく い素材の容器を用いることが大切であり，特に今回安定剂の添加 は必要がないと判断した。

\section{2 アミノアルキルゲルの調製}

$\mathrm{GM}$ ゲルの場合， $\mathrm{AH}$ 基， $\mathrm{AB}$ 基掞よび $\mathrm{ABCB}$ 基を尊入した ところ，ゲルの収縮や凝集は認められなかった。むた、アミノア ルキル基尊入前と比較して，校正曲線の形状，耐玨強度にはほ之 んど変化が見られず，生体成分分離用の担体としての好ましい性 質を保持していることがわかった。一方， Sepharose ${ }^{\circledR}$ CL-4 B では Riethorst の報告20)にあると拈り，ゲルの著しい収縮や凝集 が見られた。 $\mathrm{AH}$ 基を導入した各ゲルの光学顕微踣写真を図 3 （a，b）に示した。AH-GM ゲルが黑く見えるのは，光の透過珄

25）化血砄, コンファット ${ }^{\mathbb{B}} \mathrm{F}$ パンフレット（1992）.
が悪いからであり，GM ゲルのマトリックスが密であることに起 因しているものと考えられた。このことは GM ゲルの耐圧強度 が高いことに大きく関係しているものと推測された。

\section{3 バッチ法による FVIII の保持实験}

調製した $\mathrm{AH}-, \mathrm{AB}-, \mathrm{ABCB}-の$ 各ゲルを用いて，バッチ法に より FVIII への親和性を調べた。結果を表 2 に示した。GM ゲ ル, Sepharose ${ }^{\circledR} \mathrm{CL}-4 \mathrm{~B}$ 共に AH-ゲルが最も高い F VIII 保持 量を示し， Riethorst の報告20)を哓付ける結果となった。以後 AHーゲルを中心に検討することにした。

次に各種ゲルに AH 基を導入しまた市肘の EAH Sepharose ${ }^{\circledR}$ $4 \mathrm{~B}$ を睛入し，F VIII の保持量を調べた。各 $\mathrm{AH}$-ゲルの物性を表 3 に，またバッチ法による F VIII の淟度と保持德の関係を図 4 に 示した。AH-GM ゲルの場合，ゲルの Mlim が大きくなるに従 って FVIII の保持量が增加し, AH-GM 10000 が最も高い值を示 した。これは FVII と vWF が巨大な複合体を形成しているため, 孔径の大きいゲルほど，F VIII-vWF 複合体が内部まで入りやすく なり，保持䕗が增えたと考えた。一方，AH-GM 1000 ではゲル の内部の $\mathrm{AH}$ 基が十分使われて括らず，F 政一VWF 複合体の大 部分がゲル表面に保持されているものと考えた。このFVIIIの保

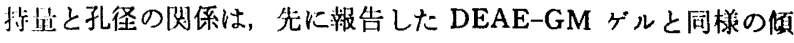
向を示した ${ }^{16)}$ 。 
Wagner らは, Biogel ${ }^{\circledR} \mathrm{A}-15 \mathrm{~m}$ を用いたサイズ排除クロマト グラフィーによって, F VIII-vWF 複合体をカラムの $V$ 。の位置 に溶出させている ${ }^{26)}$ このゲルの Mlim は PEG 換算で約 $5 \times$ $10^{5}$ であり，図4 の結果を裏付けるものとなっている。すなわち, F UII-vWF 複合体の一部しか空孔に入れないAH-GM 1000 よ り，十分大きな空孔をもつ AH-GM 10000 が有利と判断できた。 また, Pepper はカラムを用いたアフェレーシスの総説の中で, カラムの空孔が通過する分子サイズの 2 倍の時, 吸着面積の平均 5\%を使用するのみであり，効率を 80〜90\% に上げるには，空 孔の大きさは分子サイズの 10２0 倍のものが必要であるとして いる27。ちなみに，血夜タンパク質で $1 \times 10^{7}$ の分子量のものは， 平均サイズが $30 \mathrm{~nm}$ と報告されているる ${ }^{28)}$ 。 AH-GM 10000 の平均 細孔径は $300 \mathrm{~nm}$ であることから，この考察は，ゲルと FVIIIvWF 複合体の関係にも適用できるものと考えた。なお， $\mathrm{AH}$ GM 100000 (Mlim $1 \times 10^{8}$ ) では Fyll の保持量は大幅に低下し た。これは，ゲルのマトリックスが少なくなり，FＵII を保持でき る表面積が減少したためと考えた。従って，F纤を保持させるゲ ルの孔径はただ大きければ良いといらものではなく，表面積と孔 径が適切でなければならないことがわかった。

\subsection{HPLC による FVIII の分離}

3.4.1 ゲルの選定：AH 基導入時に凝集を起こしたゲルでは, カラム内で均一な拡散が起こらないと考え, 凝集を起こさなかっ た AH-GM 3000，AH-GM 10000 および市販の EAH Sepha$\operatorname{rose}^{\circledR} 4 \mathrm{~B}$ を用いて比較検討を行らことにした。ゲルの物性の一 つである校正曲線と耐流速特性を図 5 と図 6 にそれぞれ示した。 AH-GM ゲルはマクロポアを有しながらも，耐圧性にすぐれ HPLC 用分離成として好ましい特徵を備えていることがわかっ た。

3.4.2 FVIII の溶出举動の検討：FUII-vWF 複合体（pI 4.0) の $\mathrm{AH}$ 基への保持については, DEAE 基と同じ様にイオ ン交换的な作用とアルキル基の蹯水的な作用が考えられる。そこ で溶出用緩衝液中の壏濃度を食塩と塩化カルシウムを用いてそれ

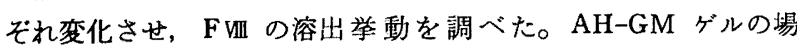
合の結果を図 $7(\mathrm{a}, \mathrm{b})$ に示した。食塩では浱度を約 $1 \mathrm{M}$ に上 げてもFVIIIはほとんど溶出せず，ごくわずか共存タンパク質 が溶出しただけであった。一方, 塩化カルシウムでは, F VII, 共存タンパク質ともに溶出が認められた。この結果, $\mathrm{AH}$ 基に対 する F VIII，共存タンパク質の保持機構は，イオン交換および疎 水的な作用が支配的と思われたが，それたけでは図 7 (a， b) の 挙動は説明できないことがわかった。上記二つのモード以外にど のようなモードが作用しているかは興味深いため, 今後の検討課 題としたい。

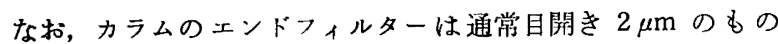
が一般的に用いられているが，F㑑が溶出する際，圧力差 （AP）の急激な上昇が認められた。この傾向はカラムへの負荷量 が多いほど顕著であった。クリオ溶液はあらかじめ $0.45 \mu \mathrm{m}$ の フィルターで沪過しており，カラムへの負荷の際 $\Delta P$ の上昇はな

26) K.M. Brinkhous, H.C. Hemker, "Handbook of Hemophilia", Excerpta Medica, Amsterdam (1975) pp.61 76.

27) D.S.Pepper, Apheresis Bulletin, 1, 114(1983).

28）山口定市, 勝田慶雄, 高分子, 37,324 (1988).
かったことから，濃縮された FVIII-vWF 複合体がカラム出口側 のフィルターに集まるために起きると考えた。実際, 目詰まりを 起こしたフィルターから，F VIII が検出されたため，カラムのフィ ルターを目開き $20 \mu \mathrm{m}$ のものに変えることにした。以後, $\Delta P$ の上昇はまったくなく，また F VII の回収率も大きく向上するこ とがわかった。

3.4.3 HPLC による FVIII の分離：AH-GM 10000 を用いた 時のクロマトグラムと分析結果を図 8 と表 4 に示した。またAH一 GM 3000, AH-GM 10000 扎よび EAH Sepharose ${ }^{\circledR} 4$ B の各実 験結果を表 5 にまとめた。

EAH Sepharose ${ }^{\circledR} 4 \mathrm{~B}$ では, バッチ試験の結果ど拈り, カラム 法においても，FVIII の保持量（率）は低かった。一方 AH-GM ゲルでは実験ごとに高いFVIII 保持量 (率) が得られ, バッチ 試験の結果を反映できた。カラム分離の後の比活性は原料クリオ の比活性に大きく左右され, 十分な脱フィブリノーゲン処理を行 ったクリオほど, 分離後の平均比活性は高かった。しかし, 精製 度で比較した場合, あまり大きな差は認められなかった。次に負 荷量とカラム分離の後の比活性の関係は, 原料クリオの比活性が 同じであれば，負荷量が少ないほど，分離後の平均比活性及び精 製度は大きく向上する傾向が認められた。

これはクリオ中に $\mathrm{AH}$ 基に対して親和性を持つことが報告さ

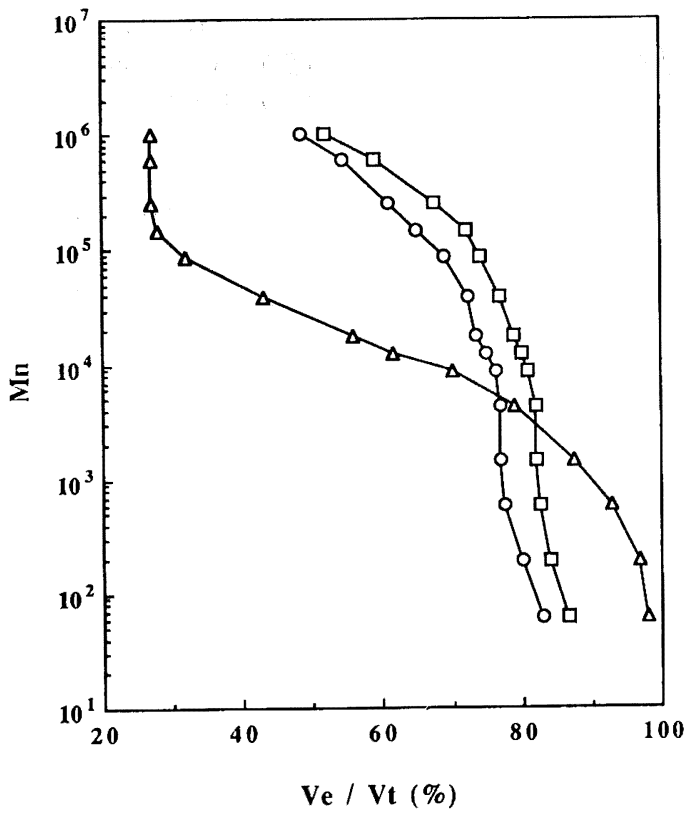

Fig. 5 Representative calibration curves of $\mathrm{AH}$ matrices $\mathrm{Ve}$ : Elution volume, $\mathrm{Vt}$ : Column bed volume

(O) AH-GM $3000(20 \sim 44 \mu \mathrm{m})$,

(ロ) AH-GM $10000(20 \sim 44 \mu \mathrm{m})$,

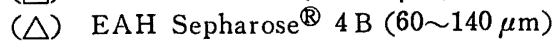

HPLC conditions

$\begin{array}{ll}\text { Pump } & : \text { Shimadzu LC-6A } \\ \text { Column size } & : 6 \mathrm{~mm} \times 100 \mathrm{~mm} \\ \text { Flow rate } & : 1.0 \mathrm{~m} l / \mathrm{min}(\mathrm{AH}-\mathrm{GM}), \\ & 0.2 \mathrm{~m} l / \mathrm{min}\left(\mathrm{EAH} \text { Sepharose }{ }^{\circledR} 4 \mathrm{~B}\right) \\ \text { Detector } & : \text { RI } \\ \text { STD } & : \text { PEG } \\ \text { Mobile phase } & : \text { Pure water }\end{array}$




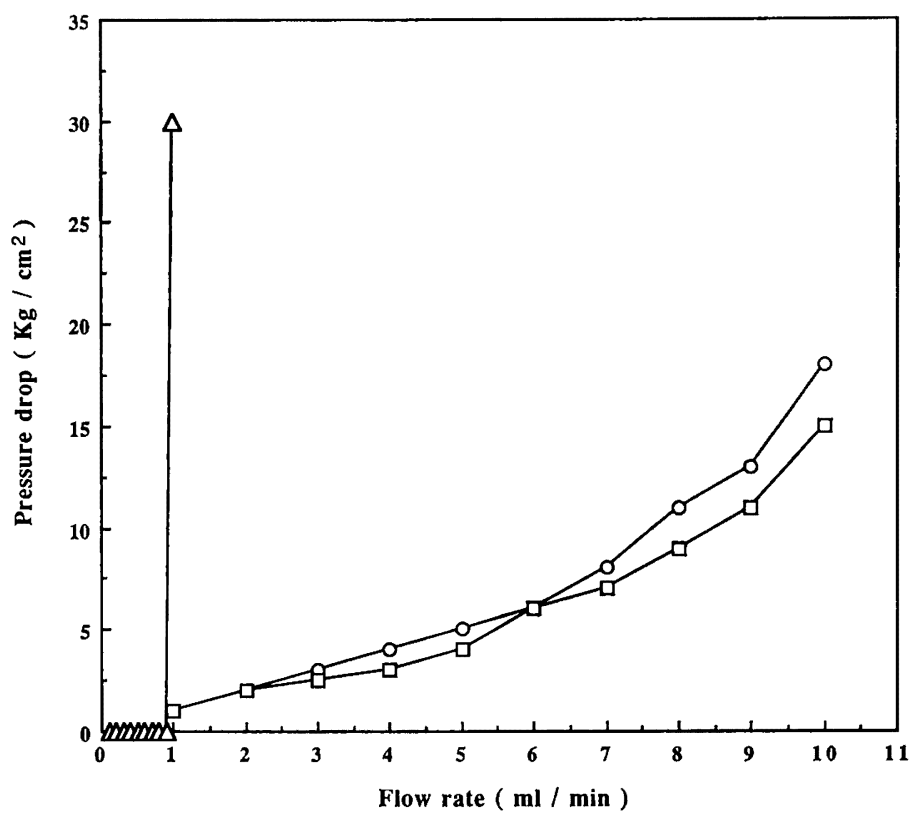

Fig. 6 Relationship between the flow rate and the pressure drop of $\mathrm{AH}$ matrices

(O) AH-GM $3000(20 \sim 44 \mu \mathrm{m})$, (口) AH-GM $10000(20 \sim 44 \mu \mathrm{m})$,

$(\triangle)$ EAH Sepharose ${ }^{\circledR} 4 \mathrm{~B}(60 \sim 140 \mu \mathrm{m})$

HPLC conditions

Pump : Shimadzu LC-7A

Column size : $6 \mathrm{~mm} \times 100 \mathrm{~mm}$

Mobile phase : Pure water

Table 4 Analytical data for factor VII in the HPLC fractions with AH-GM 10000 column

\begin{tabular}{|c|c|c|c|c|c|c|}
\hline \multirow[t]{2}{*}{ Fraction } & \multirow[t]{2}{*}{ Elution buffer ${ }^{a)}$} & \multicolumn{2}{|c|}{ Recovery of FVIII } & \multicolumn{2}{|c|}{ Recovery of proteins } & \multirow{2}{*}{$\begin{array}{l}\text { Specific activity (U/mg-protein) } \\
\text { Each fraction }\end{array}$} \\
\hline & & Amount (U) & Yield $(\%)$ & Amount (mg) & Yield $(\%)$ & \\
\hline $1^{b)}$ & (A) $+1 \mathrm{mM} \mathrm{CaCl} 2$ & 0 & 0 & 0.33 & 6.7 & 0 \\
\hline 2 & (A) $+25 \mathrm{mM} \mathrm{CaCl}_{2}$ & 0 & 0 & 0.60 & 12.3 & 0 \\
\hline 3 & (A) $+50 \mathrm{mM} \mathrm{CaCl}_{2}$ & 0.01 & 0.2 & 0.53 & 10.8 & 0.02 \\
\hline 4 & (A) $+75 \mathrm{mM} \mathrm{CaCl}$ & 0.22 & 4.8 & 0.45 & 9.2 & 0.49 \\
\hline 5 & (A) $+150 \mathrm{mM} \mathrm{CaCl}$ & 0 & 0 & 0 & 0 & 0 \\
\hline 6 & (A) $+150 \mathrm{mM} \mathrm{CaCl}_{2}$ & 0.54 & 11.7 & 0.004 & $<0.01$ & 135 \\
\hline 7 & (A) $+150 \mathrm{mM} \mathrm{CaCl}$ & 1.17 & 25.3 & $<0.001$ & $<0.01$ & $>1170$ \\
\hline 8 & (A) $+150 \mathrm{mM} \mathrm{CaCl}$ & 0.81 & 17.5 & 0.025 & 0.4 & 32.4 \\
\hline 9 & (A) $+150 \mathrm{mM} \mathrm{CaCl}$ & 0.52 & 11.3 & 0.011 & 0.2 & 47.27 \\
\hline 10 & (A) $+500 \mathrm{mM} \mathrm{CaCl}$ & 0.73 & 15.8 & 1.97 & 40.3 & 0.37 \\
\hline Sum & & 4.00 & 86.6 & 3.91 & 79.9 & 76.0 (Mean of Fra. 6 9) \\
\hline
\end{tabular}

$4.62 \mathrm{U}$ of $\mathrm{F}$ VIII with $4.89 \mathrm{mg}$ of total proteins were applied.

a) (A) : $20 \mathrm{mM}$ Tris- $\mathrm{HCl}, 100 \mathrm{mM} \mathrm{NaCl}(\mathrm{pH} 7.4)$.

b) Breakthrough.

れているフィブリノーダン, フィブロネクチンなど20)のタンパク 質が多く存在するためと推察されるが，今回クリオ中の各タンパ ク質と AH-GM ゲルに対する親和性については検討を行わなか った。AH-GM ゲルはクリオ中のタンパク質組成によって，その 性能が大きく変わることがわかったため，どのような組成のクリ オが最も AH-GM ゲルを朋いた F UII の分離に嗔しているか は，今後詳細な検討が必要と思われた。
3.5 DEAE-GM カラムと AH-GM カラムの連結による FVIII の分離

\subsubsection{AH-GM ゲルの食塩存在下での FVIII の保持量 :}

FUII の精製プロセスに拈いて, 粗製クリオは初期の段階でイ オン交換法を用いて精製するのが一般的である。本研究でも DEAE-GM ゲル ${ }^{16)}$ で精製した後のクリオをAH-GM ゲルを用い て精製する検討を行った。

AH-GM ゲルに吸着された FUII は約 $1 \mathrm{M}$ の食塩を含む綬衝 液でもほとんど溶出しないことが 3.4 .2 の結果からわかってお 

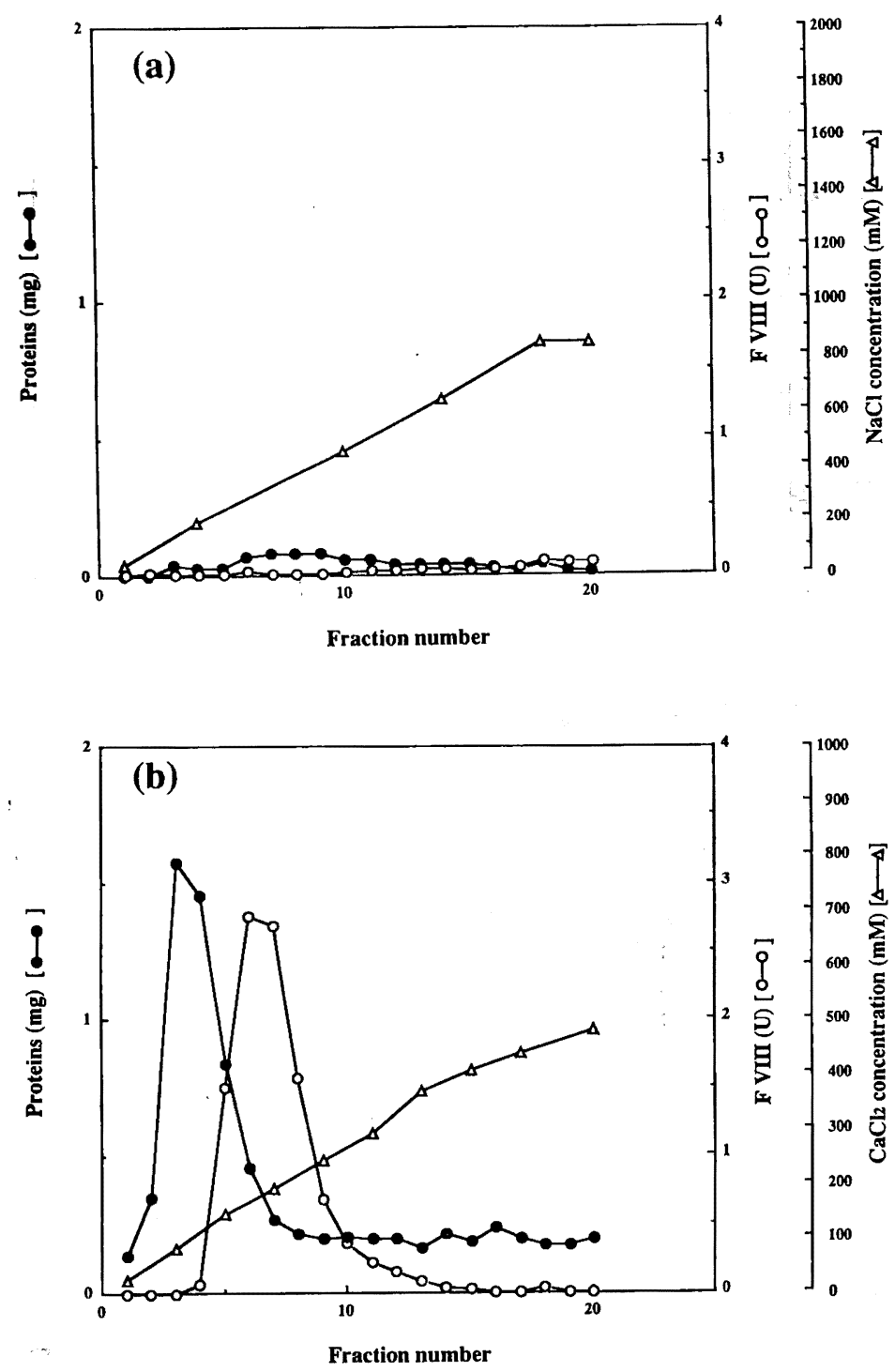

Fig. 7 Elution profile of plasma cryoprecipitate fraction in HPLC on an AH-GM 3000 column HPLC conditions
Pump : Shimadzu LC-6A
Column : AH-GM $3000(6 \mathrm{~mm} \times 100 \mathrm{~mm}$, bed volume $2.83 \mathrm{ml})$
Flow rate $: 1.0 \mathrm{~m} l / \mathrm{min}(2 \mathrm{~m} / \mathrm{h})$
Detector : UV
Wavelength : $280 \mathrm{~nm}$
Elution buffer : (a) $20 \mathrm{mM}$ Tris- $\mathrm{HCl}, 1 \mathrm{mM} \mathrm{CaCl} 2$ (pH 7.4) and 80 min linear gradient from 100 to $850 \mathrm{mM} \mathrm{NaCl}$
(b) $20 \mathrm{mM}$ Tris- $\mathrm{HCl}, 100 \mathrm{mM} \mathrm{NaCl}(\mathrm{pH} \mathrm{7.4)}$ and $80 \mathrm{~min}$ linear gradient from 1 to $480 \mathrm{mM} \mathrm{CaCl} 2$
Cryoprecipitate : (a) $24.5 \mathrm{U}$ of FVII with $9.3 \mathrm{mg}$ of total proteins and (b) 17.4 $\mathrm{U}$ of FVII with $7.7 \mathrm{mg}$ of total proteins were applied respectively.

ク, DEAE-GM カラムからの溶出液は，脱塩処理をせずそのま ま AH-GM ゲルに負荷できるものと考えられる。そこで, クリ オ中に高濃度の食塩を存在させ，F卭 の保持にどのような影響 があるのか調べた。結果を图 9 亿示した。クリオ中の食塩濃度を $100 \mathrm{mM}$ から $500 \mathrm{mM}$ に変化させた場合, F倓 の保持量は約 $35 \%$ の低下が認められたが，それでも十分な FVIII 保持量を持
っていることが確認された。またりりオをイオン交換カラムによ って精製すると F VIII の純度は 10 倍以上に向上しているため, F UII の保持量はバッチ試験の結果ほどには実際は低下しないる のと考えられた。

3.5.2 DEAE-GM カラムと AH-GM カラムの連結による FVIII の分離：比活性が $0.17 \mathrm{U} / \mathrm{mg}$-protein の脱フィブリノー 


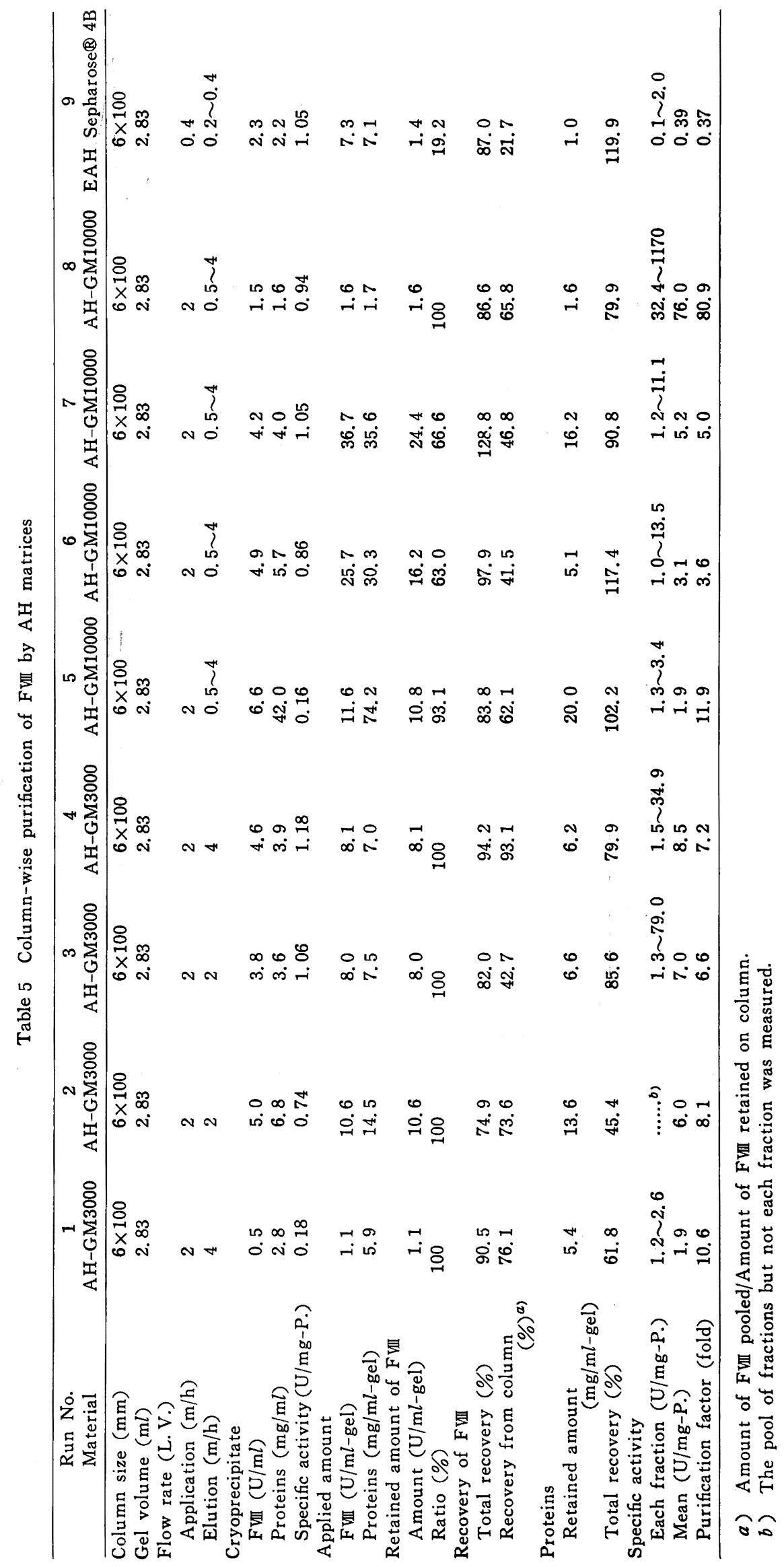




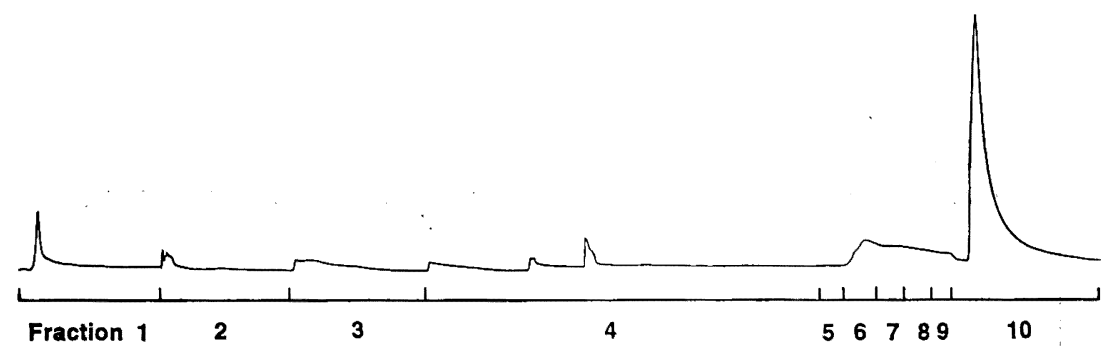

$\overline{0 \text { Elution time ( } \min )} 100$

Fig. 8 Elution profile of plasma cryoprecipifate fraction in HPLC on an AH-GM 10000 column

HPLC conditions

$\begin{array}{ll}\text { Pump } & : \text { Shimadzu LC-6A } \\ \text { Column } & : \text { A } \perp \text { GM } 10000(6 \mathrm{~mm} \times 100 \mathrm{~mm} \text {, bed volume } 2.83 \mathrm{ml}) \\ \text { Flow rate } & : 0.25 \sim 2.0 \mathrm{~m} l / \mathrm{min}(0.5 \sim 4 \mathrm{~m} / \mathrm{h}) \\ \text { Detector } & : \mathrm{UV} \\ \text { Wavelength } & : 280 \mathrm{~nm}\end{array}$

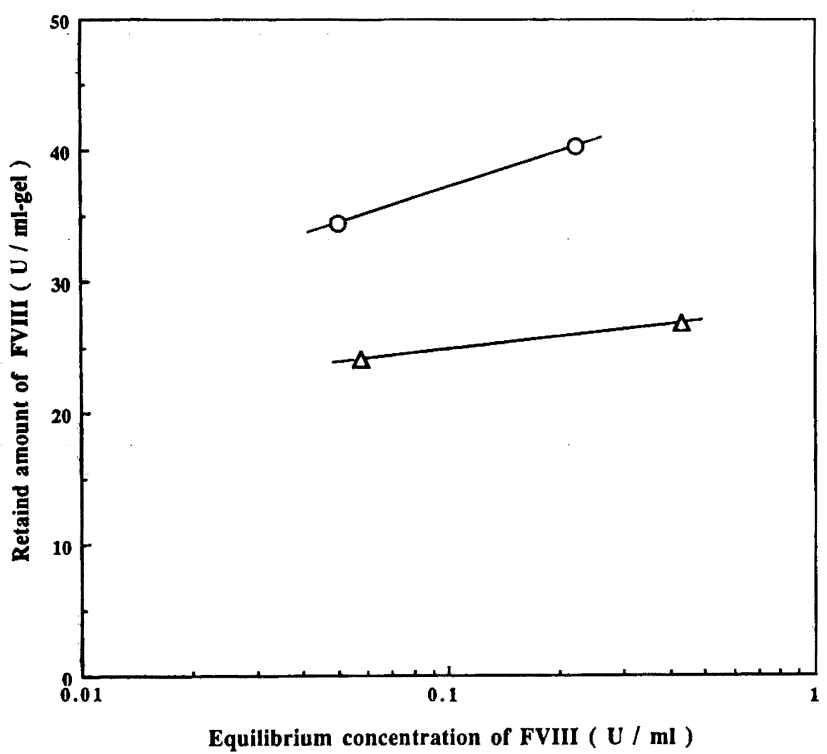

Fig. 9 Correlation of the amount of FVII retained on AH-GM 10000 to it ${ }^{2}$ concentration Experiments were carried out at $20^{\circ} \mathrm{C}$ for $1 \mathrm{~h}$ using cryoprecipitate solution in the presence of $\mathrm{NaCl}$. (O) $20 \mathrm{mM}$ Tris- $\mathrm{HCl}, 1 \mathrm{mM} \mathrm{CaCl}, 100 \mathrm{mM} \mathrm{NaCl}(\mathrm{pH} \mathrm{7.4})$,

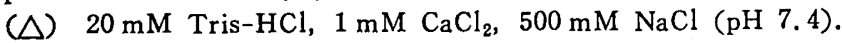

Conditions
Gel volume : $50 \mu l$
Cryoprecipitate : $1.77 \mathrm{U} / \mathrm{ml}(1.86 \mathrm{U} / \mathrm{mg}$-protein $) \times 700 \sim 1100 \mu l$

ゲン処理を行っていない粗製クリオを DEAE-GM 10000 カラム に負荷し，その溶出フラクションをそのまま AH-GM 10000 カ ラムに負荷した時のクロマトグラムを図 10 に，また分析結果を 表 6 に示した。DEAE-GM 10000 カラムから溶出させた 1000 $\mathrm{mM}$ の塩化ナトリウムを含むフラクションを AH-GM 10000 カ ラムに負荷した場合でも，FVIII はほとんど保持され溶出しなか った。また， $500 \mathrm{mM}$ 塩化カルシウムで溶出させたフラクション の純度は $45 \mathrm{U} / \mathrm{mg}$-protein であり, 原料クリオに対して 260 倍の 精製度が得られた。表 5 の Run 1 および 5 の平均比活性が約 2
U/mg-protein あったことを考えると, DEAE-GM カラムとの 連結による方法は，かなり有効であると考えられた。な拉，精製 タンパク質の純度検定において，一般に SDS-ポリアクリルアミ ト電気泳動法 (SDS-PAGE) が用いられている。しかし, F VII の場合, この方法では，モノクローナル抗体を用いたカラムクロマ トグラフィーにより，極めて高純度に精製した標品にしか F VII のバンドを検出できないことが経験的に知られている29)。また，

29) I. M.Nilsson, Scand. J. Haematol. Suppl., 33, 21 (1984). 


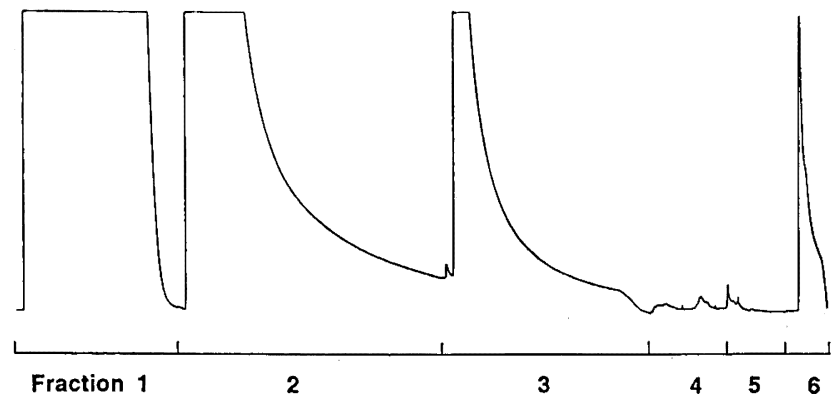

0 Elution time ( $\mathrm{min}$ ) 100

Fig. 10 Elution profile of plasma cryoprecipitate fraction in HPLC from the DEAE-GM 10000 and AH-GM 10000 columns

HPLC conditions

Pump : Shimadzu LC-6A

Column : DEAE-GM $10000(6 \mathrm{~mm} \times 100 \mathrm{~mm}$, bed volume $2.83 \mathrm{ml})$

AH-GM $10000(10 \mathrm{~mm} \times 100 \mathrm{~mm}$, bed volume $7.85 \mathrm{ml})$

Flow rate $: 1.0 \sim 2.0 \mathrm{ml} / \mathrm{min}(1 \sim 4 \mathrm{~m} / \mathrm{h})$

Detector : UV

Wavelength : $280 \mathrm{~m}$

Table 6 Analytical data for factor VIII in the HPLC fractions with DEAE-GM 10000 and AH-GM 10000 columns

\begin{tabular}{|c|c|c|c|c|c|c|}
\hline \multirow[t]{2}{*}{ Fraction } & \multirow[b]{2}{*}{ Elution buffer ${ }^{a)}$} & \multicolumn{2}{|c|}{ Recovery of FVII } & \multicolumn{2}{|c|}{ Recovery of proteins } & \multirow{2}{*}{$\begin{array}{l}\text { Specific activity (U/mg-protein) } \\
\text { Each fraction }\end{array}$} \\
\hline & & Amount (U) & Yield (\%) & Amount (mg) & Yield (\%) & \\
\hline $1^{b)}$ & (A) & 48.52 & 28.9 & 901.1 & 92.4 & 0.05 \\
\hline 2 & (A) $+200 \mathrm{mM} \mathrm{NaCl}$ & 0.59 & 0.4 & 29.3 & 3.0 & 0.02 \\
\hline 3 & (A) $+250 \mathrm{mM} \mathrm{NaCl}$ & 16.13 & 9.6 & 8.4 & 0.9 & 1.92 \\
\hline $4^{c)}$ & (A) $+1000 \mathrm{mM} \mathrm{NaCl}$ & 0.02 & $<0.01$ & 0.1 & $<0.01$ & 0.13 \\
\hline 5 & (B) $+100 \mathrm{mM} \mathrm{CaCl}_{2}$ & 0 & 0 & $<0.001$ & $<0.01$ & 0 \\
\hline 6 & (B) $+500 \mathrm{mM} \mathrm{CaCl}_{2}$ & 41.66 & 24.8 & 0.9 & 0.1 & 44.8 \\
\hline Sum & & 106.92 & 63.7 & 939.8 & 96.4 & \\
\hline
\end{tabular}

167.7 U of FVII with $975.0 \mathrm{mg}$ of total proteins were applied.

Fraction 4 was obtained by the connection of DEAE-GM 10000 and AH-GM 10000 columns.

a) (A) : $20 \mathrm{mM}$ Tris- $\mathrm{HCl}, 1 \mathrm{mM} \mathrm{CaCl}$ (pH 7.4), (B) : $20 \mathrm{mM}$ Tris- $\mathrm{HCl}$ (pH 7.4)

b) Breakthrough of DEAE-GM 10000 column.

c) Breakthrough of $\mathrm{AH}-\mathrm{GM} 10000$ column.

前述のように FVIII はWF と複合体を形成しており, vWF の血 墏中での濃度が，モル比で FyII の約 300 倍存在しているため， 仮に 90\% 以上遊離型の vWF を除去しても，まだモル比で王倒 的に多く $\mathrm{vWF}$ が存在する。この vWF は，それ自身が，ジスル フィド結合により，80 万〜1400 万に及ぶオリゴマーを形成し， SDS-アガロース雪気泳動法においてはしご状の多数のバンドと ・して検出されるため, この方法は vWF の純度検定に沶いてさえ 必ずしも適していないことが知られている ${ }^{299}$ 。したがって，今回 の研究では SDS ゲル電気泳動法による純度検定は行わず, 比活 性のみ測定することにした。

今回, DEAE-GM カラムと AH-GM カラムとの連結による数 回の実験では, 分離後の比活性は 21〜 45 U/mg-protein, カラム からの回収率は 27〜 41\% であり, DEAE-GM カラムとの連結に よる方法は，粗製クリオを用いた FVIII の精製プロセスに適用で きるものと考えられた。一方，精製プロセスに適用するにはカラ
ムからの FVIII の回収率の向上スケールフップによる実証試 験，および動物実験，臨床試験による安全性の確認が不可欠であ り，今後の課題と考えられた。

\section{4 結 論}

アミノアルキルグルコマンナンゲルを用いた HPLC による血 液凝固第 8 因子 (FVII) の分離を検討した結果, 以下のことが明 らかになった。

（1）F项 への親和性が報告されている 4-フミノブチル， 4-(4-アミノブチルカルバモイル)ブチル，6-アミノヘキシルの各 アミノアルキル基をグルコマンナンゲルに尊入した結果, 6-アミ ノヘキシル基が最も高い親和性を示した。これは, 市販のゲルに も同様のことがいえた。

（2）6-アミノヘキシル基を導入したグルコマンナンゲル (AH-GM ゲル) への FUII の保持量はゲルの孔径に大きく左右 
された。特に PEG 換算で Mlim 1000 万の AH-GM 10000 が最 も高いF证の保持量を示した。しかし、これ以上孔径の大きい ゲルでは逆に FVIII の保持量は低下した。

(3) AH-GM 10000 は市肘の EAH Sepharose ${ }^{\circledR} 4 \mathrm{~B}$ の 10 倍以上の高いF VIII 保持量が得られた。またカラム試験に打いて も, 通液安定性にすぐれ, 試料負荷の時の流速が $2 \mathrm{~m} / \mathrm{h}$ であって も，高いF诅 保持量（率）を示した。

（4） AH-GM ゲルは比活性の高いクリオほど, F四の保持 量が高く、またカラム試験において精製度が向上する傾向が認め られた。一方，粗精クリオを用いた場合，その性能が十分発揮さ れないことがわかった。血液製剤ブロセスに適用する場合，イオ ン交换法との併用が有効と考えられた。

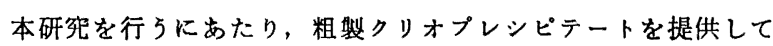
頂いた財団法人化学及血清療法研究所 (化血研) の大橋高明博上, 並びに終始有用なこ助言を頂きました，化血研井上博䀬先生，梁 田工業株式会社総合研宛所上甲 勲, 松下聿宏両氏にお礼を申し 上げます。最後に，本研宛の種々の测定に拈いて親切なこ指導を して頂きました能本大学医学部付属病院中央検査部の湶谷陽子博 士に感謝します。

本研究の内容の一部は 10th International Symposium on HPLC of Proteins, Peptides, and Polynucleotides (1990 年 10 月, Wiesbaden) で発表済み。

Application of 6-Aminohexylated Macroporous Glucomannan

Gel to High-Performance Liquid Chromatography for Purification of Coagulation Factor VIII

Masato Yamaguchi*, Tetsuro Yamamoto ${ }^{\dagger}$, Masa-aki Wakita and Yoshiaki Morozarot†

Kurita Water Industries Ltd.; 4-7, Nishi-shinjuku 3-chome, Shinjuku-ku, Tokyo 160 Japan

† Department of Molecular Pathology, Graduate School of Medical Sciences,

Kumamoto University; 2-2-1 Honjo, Kumamoto-shi 860 Japan

t† Department of Industrial Chemistry, Kumamoto Institute of Technology ; 4-22-1 Ikeda, Kumamoto-shi 860 Japan

6-Aminohexylated macroporous glucomannan gel beads (AH-GM gel) have been developed and applied to chromatographic separation of blood coagulation factor UII (F VII) in plasma cryoprecipitate fraction.

Retained capacity of FVII on various kinds of $\mathrm{AH}$-spherical gels was measured by a batchwise method and was apparently dependent on exclusion limit (Mlim) of the gels. AH-GM gel $\left(M \lim 1 \times 10^{7}\right)$ possessed the capacity at least 10 fold higher than EAH Sepharose ${ }^{\circledR} 4 \mathrm{~B}$.

The HPLC system using an AH-GM gel column also showed strong retention and good elution recovery of $\mathrm{F}$ VII under the operational conditions at $0.5 \sim 4 \mathrm{~m} / \mathrm{h}$ flow rate. 